\title{
Chemical Inhibitors of the Calcium Entry Channel TRPV6
}

\author{
Christopher P. Landowski • Katrin A. Bolanz • Yoshiro Suzuki • Matthias A. Hediger
}

Received: 26 April 2010 / Accepted: 13 August 2010 / Published online: 6 November 2010

(C) Springer Science+Business Media, LLC 2010

\begin{abstract}
Purpose Calcium entry channels in the plasma membrane are thought to play a major role in maintaining cellular $\mathrm{Ca}^{2+}$ levels, crucial for growth and survival of normal and cancer cells. The calcium-selective channel TRPV6 is expressed in prostate, breast, and other cancer cells. Its expression coincides with cancer progression, suggesting that it drives cancer cell growth. However, no specific inhibitors for TRPV6 have been identified thus far.
\end{abstract}

Methods To develop specific TRPV6 inhibitors, we synthesized molecules based on the lead compound TH-II77, reported to inhibit calcium entry channels in prostate cancer cells in vitro and in vivo.

Results We found that one of our compounds (\#03) selectively inhibited TRPV6 over five times better than TRPV5, whereas $\mathrm{TH}-\mathrm{II} 77$ and the other synthesized compounds

\author{
C. P. Landowski · K. A. Bolanz · Y. Suzuki • M. A. Hediger $(\square)$ \\ Institute of Biochemistry and Molecular Medicine, University of Bern \\ Bern $\mathrm{CH}-30$ I2, Switzerland \\ e-mail: matthias.hediger@mci.unibe.ch \\ M. A. Hediger \\ Swiss National Center of Competence in Research, NCCR- \\ TransCure, University of Berne \\ Switzerland \\ Present Address: \\ C. P. Landowski \\ VTT Technical Research Center of Finland \\ Espoo, Finland \\ Present Address: \\ K. A. Bolanz \\ Agroscope, Swiss Federal Office for Agriculture \\ Bern, Switzerland \\ Present Address: \\ Y. Suzuki \\ National Institute for Physiological Sciences \\ Okazaki, Japan

preferentially inhibited TRPV5. The $I_{50}$ value for growth inhibition by blocking endogenous $\mathrm{Ca}^{2+}$ entry channels in the LNCaP human prostate cancer cell line was $0.44 \pm 0.07 \mu \mathrm{M}$ compared to $\mathrm{TH}-\mathrm{I} I 77(50 \pm 0.4 \mu \mathrm{M})$.

Conclusions These results suggest that compound \#03 is a relatively selective and potent inhibitor for TRPV6 and that it is an interesting lead compound for the treatment of prostate cancer and other cancers of epithelial origin.

KEY WORDS breast cancer · calcium channel · chemical inhibitors · prostate cancer. TRPV6

\section{ABBREVIATIONS}

CRAC $\mathrm{Ca}^{2+}$ release-activated $\mathrm{Ca}^{2+}$

FBS fetal bovine serum

LNCaP lymph node carcinoma of the prostate

NFAT nuclear factor of activated T-cells

NMM N-methylmorpholine

Orail calcium release-activated calcium channel protein I

PyBOP Benzotriazol-I-yl-oxytripyrrolidinophosphonium

SCID severe combined immunodeficiency

SOC store-operated calcium channel

STIMI stromal interaction molecule I

THF Tetrahydrofuran

TRP transient receptor potential

\section{INTRODUCTION}

Prostate cancer is the most common form of cancer in men in the Western world (accounting for one-third of diagnosed cancers) and the second overall leading cause of death from cancer in Europe and the United States. Tumor invasion and metastasis are the primary cause of death (1). At the time of diagnosis, over $70 \%$ of men have lymph 
node metastases, which subsequently spread to bone in the pelvic and lumbar vertebral column (2-4). Epidemiologic studies have linked diets rich in calcium to a higher risk of prostate cancer (5-7). However, the biological basis for this link is still unknown. The evidence linking calcium and prostate cancer suggests a critical role for calcium channels in the progression of the disease. Understanding this role may lead to the development of novel therapeutics to improve prostate cancer treatment.

In non-excitable cell types and some excitable cells, store-operated calcium channels (SOCs) in the plasma membrane serve to replenish intracellular calcium stores in the endoplasmic reticulum following agonist-elicited calcium release $(8-10)$. Besides playing a major role in store-operated calcium entry, these channels are also involved in regulating numerous important physiological processes such as cell growth, proliferation, and apoptosis. The best functionally and biophysically characterized SOC subtypes are the $\mathrm{Ca}^{2+}$ release-activated $\mathrm{Ca}^{2+}$ (CRAG) channels, originally described in immune cells (11-13) and later in various exocrine cells (e.g., prostate) involved in secretion (14,15). STIM1 and Orail have been shown to mediate CRAC currents and store-operated calcium entry in a variety of cells (16-19), but not in prostate cancer cells.

CRAC-like activities have been extensively described for the human prostate carcinoma cell lines PC-3 and LNCaP $(14,20)$. The TRPC1 and TRPV6 members of the transient receptor potential (TRP) ion channel family are the most likely molecular candidates for prostate-specific endogenous SOC or CRAC-like activities $(21,22)$. Numerous studies have linked enhanced endoplasmic reticulum $\mathrm{Ca}^{2+}$ accumulation to proliferation in prostate cancer (23-25). Moreover, endogenous SOCs play an important role in the apoptosis of LNCaP prostate cancer cells $(26,27)$.

TRPV6 is strongly expressed in advanced stages of prostate cancer, whereas there is little to no expression evident in healthy tissue and benign prostate hyperplasia (28). TRPV6 transcripts are highly expressed in lymph node metastases originating from the prostate (28), and their expression correlates to the Gleason score and pathological stage (29). There is also evidence that TRPV6 plays a role in breast cancer, being strongly expressed in malignant tissue compared to normal mammary gland tissue (30). We have demonstrated that the breast cancer cell line T47D displays decreased viability after siRNA knockdown of TRPV6 (31).

Several studies have shown that TRPV6 is involved in highly calcium-selective currents in prostate cancer cells and is regulated by intracellular calcium levels $(21,32,33)$. TRPV6mediated calcium entry has been reported to directly control the proliferation of $\mathrm{LNCaP}$ cells and promote apoptosis resistance (34). These studies suggest that TRPV6 would be a promising therapeutic target, although there have been no previous directed efforts to develop inhibitors. The few known inhibitors include two antifungal compounds econazole and miconazole and the staining dye ruthenium red.

Some evidence that it is possible to target TRPV6 in prostate cancer cells by chemical inhibitors comes from studies conducted by Haverstick et al. (35), who developed calcium channel inhibitors structurally similar to dihydropyridines. One of these compounds, TH-1177, effectively blocked store-operated calcium entry in LNCaP prostate cancer cells and inhibited fractional survival of LNCaP cells. When tested in SCID mice carrying prostate cancer cells, TH-1177 treatment prolonged the mean life span of mice by up to $38 \%$. Healthy mice that received 18 times the therapeutic dose showed no signs of toxicity. In these studies, the molecular target of TH-1177 was not identified, although TRPV6 is a likely candidate.

In this study, we make the first directed attempt to create selective inhibitors for TRPV6. Based on the abovementioned findings, we synthesized compounds that have similar structures to TH-1777 and performed biological assays to screen for TRPV6 inhibition. We identified both TRPV5and TRPV6-selective inhibitors that were effective at reducing the proliferation of prostate and breast cancer cells. Thus, these inhibitors might be interesting lead compounds in the development of a TRP-targeted cancer treatment.

\section{MATERIALS AND METHODS}

\section{Materials}

T47D cells and LNCaP cells were obtained from NIH Culture Collection. Plastic six-well cell culture dishes, 96-well cell culture dishes, and T75 cultivation flasks were purchased from BD Biosciences. RPMI-1640 medium from Invitrogen was used to culture the cells. Fetal bovine serum (FBS), trypsin, and penicillin/streptomycin for cell culture, and TRIzol reagent for total RNA purification were also purchased from Invitrogen. TaqMan Universal Master Mix and Primer Express for real-time PCR were from Applied Biosystems. siRNAs and HiPerFect transfection reagent were obtained from Qiagen. Chemicals used for synthesis were from Sigma and Novabiochem.

\section{Cell Culture}

The human breast cancer cell line T47D and the human prostate cancer cell line LNCaP were used in this study. Tumor cells were grown in T75 culture flasks in RPMI1640 medium supplemented with $10 \%$ FBS and antibiotics (100 $\mathrm{U} / \mathrm{ml}$ penicillin and $100 \mu \mathrm{g} / \mathrm{ml}$ streptomycin) in a humidified atmosphere with $5 \% \mathrm{CO}_{2}$. Cells used in these studies were between passages 30 to 45 . The cells were routinely passaged twice per week. 


\section{siRNA Treatment}

Two different siRNA molecules were used to knockdown TRPV6 expression in the LNCaP cells. The siRNA1 (target sequence): CTG CAT GTC AGA GCA CTT TAA, siRNA2 (target sequence): AAC CTG CTG CAG CAG AAG AGG, and the siRNA control: AAT CAT CTA AGC TGG CTT TGC were used to transfect into cancer cells. The cells were seeded in $2 \mathrm{ml}$ of culture medium at 400,000 cells per well in six-well plates. After $24 \mathrm{~h}$, siRNA was diluted in phenol red-free medium and delivered with HiPerFect reagent using a final siRNA concentration of $5 \mathrm{nM}$. The cells were incubated with siRNAs for $72 \mathrm{~h}$ before the total RNA was isolated using the TRIzol RNA isolation method, according to the manufacturer's protocol.

\section{Real-Time PCR}

cDNA was prepared for each sample by reverse transcription of total RNA using TaqMan reverse transcription reagents according to the manufacturer's manual, as described previously (31). For all experiments, mRNA expression was measured by real-time PCR using an Applied Biosystems 7500 Real-Time PCR System. Reactions consisted of $1 \mathrm{x}$ Master Mix, $0.9 \mu \mathrm{M}$ forward and reverse primers, and $0.2 \mu \mathrm{M}$ dual-labeled fluorescent probes each for TRPV6 and $\beta$-actin. The sequences of the forward and reverse primers for TRPV6 were 5'-GGT TCG TGG GGG TGG AA-3' and 5'-CGT GTG CGT AGC GTT GGA T-3', respectively, with the resulting amplicon being $62 \mathrm{bp}$ with a $\mathrm{T}_{\mathrm{m}}$ of $60^{\circ} \mathrm{C}$. The probe sequence for TRPV6 was 5'-ACA GGC AAG ATC TCA ACG GGC AGC-3'. The forward and reverse primer sequences for $\beta$-actin were 5'-CCT GGC ACG CAG CAC AAT-3' and 5'-GCC GAT CGA CAC GGA ATA CT-3', respectively, with the resulting amplicon being $69 \mathrm{bp}$ with a $\mathrm{T}_{\mathrm{m}}$ of $60^{\circ} \mathrm{C}$. The probe sequence for $\beta$-actin was $5^{\prime}$-ATC AAG ATC ATT GCT CCT CCT GAG CGC-3'. Primer Express was used to select primers for TRPV6 and $\beta$-actin. All primers were designed to cross exon-exon boundaries of the coding sequence. Primers were optimized and validated for the comparative $\mathrm{Ct}$ method, as described in the manufacturer's manual. ABI Prism SDS software version 1 was used for the analysis of the amplification plots. The fold change \pm SD in TRPV6 expression was normalized to $\beta$-actin.

\section{Cell Proliferation}

Prostate cancer cell proliferation experiments were carried out in 96-well plates. To determine the effect of TRPV6specific siRNAs on proliferation, 5,000 cells were seeded per well, and after $24 \mathrm{~h}$ cells were treated with $5 \mathrm{nM}$ (final concentration) for $72 \mathrm{~h}$. The effect of the synthesized compounds was determined by treating 5,000 cells for $72 \mathrm{~h}$ with $\log$ dilutions of the compound (10-0.001 mM). After incubation, the number of living cells was determined using Cell Proliferation Kit II (XTT; Roche) following the manufacturer's instructions. The absorbance was measured by an ELISA reader (Vmax, Molecular Devices) at $450 \mathrm{~nm}$, with a reference wavelength at $650 \mathrm{~nm}$. Data points were measured in triplicates.

\section{TRPV $\mathrm{Ca}^{2+}$ Uptake Inhibition}

Xenopus oocytes were injected with TRPV5 or TRPV6 cRNA and expressed for $48 \mathrm{~h}$ before assaying ${ }^{45} \mathrm{Ca}^{2+}$ uptake, as described previously (36). Uptake of ${ }^{45} \mathrm{Ca}^{2+}$ was measured in the presence of diluted inhibitor in order to calculate $\mathrm{IC}_{50}$ values.

\section{$\mathrm{Ca}^{2+}$ Uptake Activity Measurement}

Five-thousand cells per well were seeded in a black 96-well plate in $50 \mu \mathrm{l}$ of culture medium per well. After $24 \mathrm{~h}$, siRNA treatment was performed with $5 \mathrm{nM}$ siRNA as described above. Subsequently, after $48 \mathrm{~h}$, the calcium uptake activity was observed in real time using the FLIPR Calcium 3 Assay Kit (Molecular Devices), according to the manufacturer's manual. To the medium, $50 \mu \mathrm{l}$ of calcium-free loading buffer containing EGTA $(0.1 \mathrm{mM})$ was added to decrease the influence of FBS in the culture medium. Then $100 \mu \mathrm{l}$ of calcium 3 dye was added, and the plate was incubated for $1 \mathrm{~h}$ at $37^{\circ} \mathrm{C}$. The plate was put into the FlexStation. EGTA (100 mM) was added to the cells to deplete intracellular calcium stores, followed by the addition of calcium solution (100 mM). Fluorescence change (counts) showed the calcium uptake activity after siRNA.

\section{Chemical Synthesis}

A general synthesis scheme is shown in Fig. 1. Step 1 yields the amide, step 2 reduces the amide, and step 3 forms the ether bond. Step 1 in synthesis of Compound \#01: Lproline methyl ester was coupled with 4methoxyphenylacetic acid using benzotriazol-1-yl-oxytripyrrolidinophosphonium (PyBOP) and 2 equivalents of $\mathrm{N}$ methylmorpholine (NMM) to produce methyl 1-[2-(4methoxyphenyl) acetyl] pyrrolidine-2-carboxylate. In step 2, the amide was reduced to the amino alcohol with $\mathrm{LiAlH}_{4}$ and $\mathrm{AlCl}_{3}$ in dry tetrahydrofuran (THF). In step 3, the product was converted to the amine alcohol salt by dissolving the step 2 product in ethyl acetate and $15 \%$ $\mathrm{HCl} /$ ethyl acetate and evaporating the solvent with a rotary vacuum. This salt was coupled with 4chlorobenzhydrol (or other alcohol groups as in subsequent syntheses) under Williamson conditions, using catalytic para-toluenesulfonic acid $\left(p\right.$ - $\left.\mathrm{TsOH}_{\mathrm{s}}\right)$ in refluxing toluene. 
The final brownish oil was isolated using column chromatography on silica gel with a 50:50 ethyl acetate:hexane mixture. Structures were confirmed by NMR and mass spectrometry. The three-step synthesis described here provides a general method for synthesis of a large number of derivatives. The following variations were made to the above procedure to synthesize the other compounds. Compound \#02: In step 3, benzhydrol was coupled instead of 4-chlorobenzhydrol. Compound \#03: In step 3, 4-chlorophenylmethanol was used instead of 4-chlorobenzhydrol. Compound \#05: In step 1, 4dimethylaminophenylacetic acid was used instead of 4methoxyphenylacetic acid. Compound \#06: Same as \#05, except the synthesis was ended after step 2. Compound \#09: In step 1, 4-chlorophenylacetic acid was used instead of 4methoxyphenylacetic acid.

\section{Chemical Analysis}

Compound \#01: purity 90\%; ${ }^{1} \mathrm{H}$ NMR (300 MHz, DMSO$\left.\mathrm{d}_{6}\right): \delta \quad 7.25-7.15(\mathrm{~m}, 9 \mathrm{H}), 6.95-6.82(\mathrm{~d}, 2 \mathrm{H}), 6.65-6.58$ $(\mathrm{d}, 2 \mathrm{H}), 5.36(\mathrm{~s}, 1 \mathrm{H}), 3.62(\mathrm{~s}, 3 \mathrm{H}), 3.31-3.25(\mathrm{~m}, 2 \mathrm{H}), 2.90$ $2.80(\mathrm{~m}, 2 \mathrm{H}), 2.69-2.60(\mathrm{~m}, 2 \mathrm{H}), 2.56-2.52(\mathrm{~m}, 1 \mathrm{H}), 2.36-$ $2.30(\mathrm{~m}, 2 \mathrm{H}), 1.77-1.60(\mathrm{~m}, 2 \mathrm{H}), 1.56-1.44(\mathrm{~m}, 2 \mathrm{H})$; ESI-MS $436.1(\mathrm{M}+\mathrm{H})^{+}$.

Compound \#02: purity 90\%; ${ }^{1} \mathrm{H}$ NMR (300 MHz, DMSO-d $\left.)_{6}\right): \delta 7.22-7.18(\mathrm{~m}, 10 \mathrm{H}), 6.97-6.86(\mathrm{~d}, 2 \mathrm{H})$, 6.63-6.55 (d, 2H), 5.37 (s, 1H), $3.73(\mathrm{~s}, 3 \mathrm{H}), 3.32-3.24$ $(\mathrm{m}, 2 \mathrm{H}), 2.94-2.82(\mathrm{~m}, 2 \mathrm{H}), 2.72-2.61(\mathrm{~m}, 2 \mathrm{H}), 2.57-2.54$ $(\mathrm{m}, 1 \mathrm{H}), 2.37-2.28(\mathrm{~m}, 2 \mathrm{H}), 1.78-1.62(\mathrm{~m}, 2 \mathrm{H}), 1.58-1.44$ $(\mathrm{m}, 2 \mathrm{H})$; ESI-MS $402.1(\mathrm{M}+\mathrm{H})^{+}$.

Compound \#03: purity 90\%; ${ }^{1} \mathrm{H}$ NMR (300 MHz, DMSO-d $\left.{ }_{6}\right): \delta 7.41-7.30(\mathrm{~m}, 4 \mathrm{H}), 7.18-7.06(\mathrm{~d}, 2 \mathrm{H}), 6.82-$ $6.79(\mathrm{~d}, 2 \mathrm{H}), 4.47-4.44(\mathrm{~s}, 2 \mathrm{H}), 3.71(\mathrm{~s}, 3 \mathrm{H}), 3.40-3.38$ $(\mathrm{m}, 2 \mathrm{H}), 2.98-2.85(\mathrm{~m}, 2 \mathrm{H}), 2.64-2.59(\mathrm{~m}, 2 \mathrm{H}), 2.51-2.49$ $(\mathrm{m}, 1 \mathrm{H}), 2.36-2.28(\mathrm{~m}, 2 \mathrm{H}), 1.79-1.64(\mathrm{~m}, 2 \mathrm{H}), 1.62-1.51$ (m, 2H); ESI-MS $360.1(\mathrm{M}+\mathrm{H})^{+}$.

Compound \#05: purity 90\%; ${ }^{1} \mathrm{H}$ NMR (300 MHz, DMSO-d 6 ): $\delta$ 7.41-7.32 (m, 9H), 6.94-6.92 (d, 2H), 6.65$6.59(\mathrm{~d}, 2 \mathrm{H}), 5.45(\mathrm{~s}, 1 \mathrm{H}), 3.37-3.33(\mathrm{~m}, 2 \mathrm{H}), 2.92-2.89$ $(\mathrm{m}, 2 \mathrm{H}), 2.86-2.83(\mathrm{~m}, 6 \mathrm{H}), 2.72-2.65(\mathrm{~m}, 2 \mathrm{H}), 2.57-2.54$ $(\mathrm{m}, 1 \mathrm{H}), 2.37-2.28(\mathrm{~m}, 2 \mathrm{H}), 1.75-1.63(\mathrm{~m}, 2 \mathrm{H}), 1.58-1.45$ $(\mathrm{m}, 2 \mathrm{H})$; ESI-MS $449.2(\mathrm{M}+\mathrm{H})^{+}$.

Compound \#06: purity 95\%; ${ }^{1} \mathrm{H}$ NMR (300 MHz, DMSO-d $\left.{ }_{6}\right): \delta 7.14-7.11(\mathrm{~d}, 2 \mathrm{H}), 6.90-6.81(\mathrm{~d}, 2 \mathrm{H}), 4.30(\mathrm{~s}$, $1 \mathrm{H}), 3.39-3.35$ (d, 2H), 2.98-2.95 (m, 2H), 2.87-2.83 (m, $6 \mathrm{H}), 2.68-2.63(\mathrm{~m}, 2 \mathrm{H}), 2.40(\mathrm{~s}, 1 \mathrm{H}), 2.35-2.25(\mathrm{~m}, 2 \mathrm{H})$, 1.79-1.62 (m, 2H), 1.59-1.45 (m, 2H); ESI-MS 249.2 (M + $\mathrm{H})^{+}$.

Compound \#09: purity 90\%; ${ }^{1} \mathrm{H}$ NMR (300 MHz, DMSO-d $\left.\mathrm{d}_{6}\right): \delta$ 7.35-7.13 (m, 13H), $5.49(\mathrm{~s}, 1 \mathrm{H}), 3.41-3.34$ $(\mathrm{m}, 2 \mathrm{H}), 2.98-2.86(\mathrm{~m}, 2 \mathrm{H}), 2.83-2.68(\mathrm{~m}, 2 \mathrm{H}), 2.59-2.54$ $(\mathrm{m}, 1 \mathrm{H}), 2.34-2.25(\mathrm{~m}, 2 \mathrm{H}), 1.75-1.59(\mathrm{~m}, 2 \mathrm{H}), 1.56-1.44$ $(\mathrm{m}, 2 \mathrm{H})$; ESI-MS $440.1(\mathrm{M}+\mathrm{H})^{+}$.

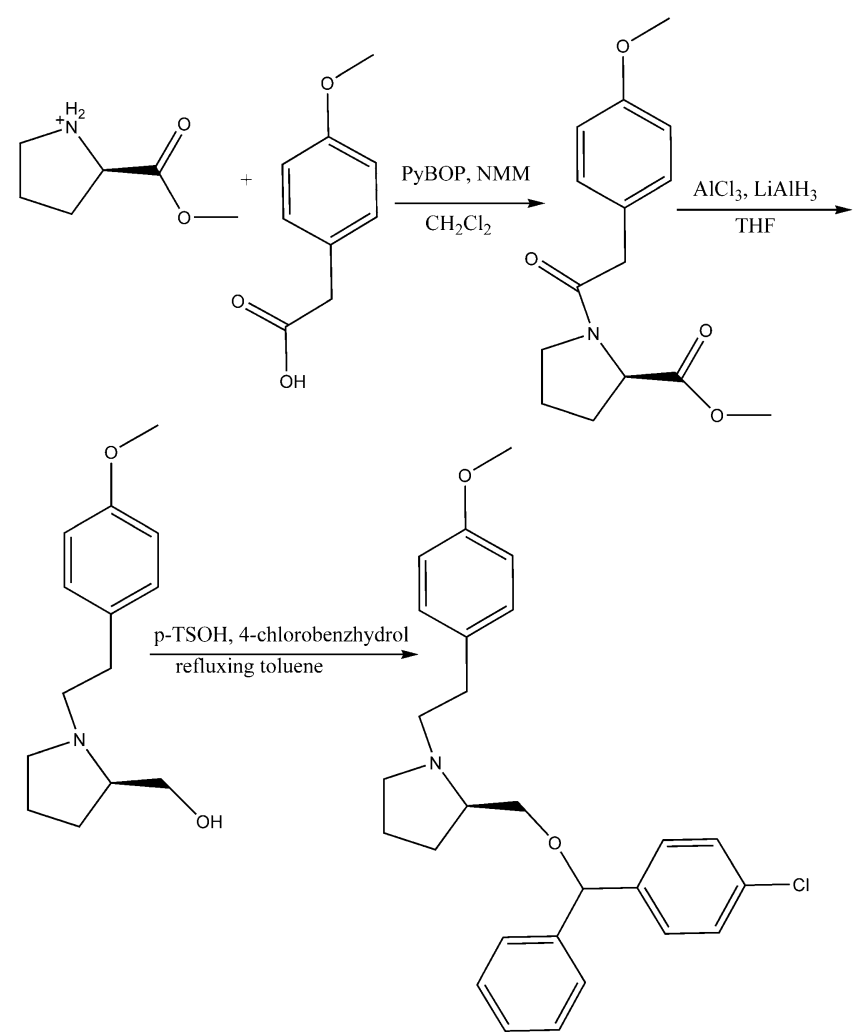

Fig. I General scheme for synthesis of chemical compounds.

\section{RESULTS}

\section{Chemical Synthesis}

To develop inhibitors of TRPV6 we synthesized a group of compounds similar to TH-1177 using a three-step method, as shown in Fig. 1. The structures of the five resulting compounds (\#02, \#03, \#05, \#06 and \#09) are shown in Fig. 2 and were confirmed by ESI-MS and NMR analysis. Compound \#01 is TH-1177. While TH-1177 has been established as an inhibitor of $\mathrm{Ca}^{2+}$ entry in prostate cancer cells (35), it has not been previously shown to be a TRPV6 inhibitor. The compounds and controls were tested for their inhibitory potential on TRPV5 and TRPV6, and for their antiproliferative effect in in vitro assays using prostate and breast cancer cells.

\section{Inhibition of TRPV5 and TRPV6}

To test the potency and selectivity of our compounds for the calcium channels TRPV5 and TRPV6, we performed ${ }^{45} \mathrm{Ca}^{2+}$ uptake assays using TRPV5- or TRPV6-expressing Xenopus oocytes. This assay allows for high protein expression and to separately express different isoforms. For each compound and control, $\mathrm{IC}_{50}$ values were calculated and are plotted in Fig. 3. The most potent TRPV6 inhibitor was 

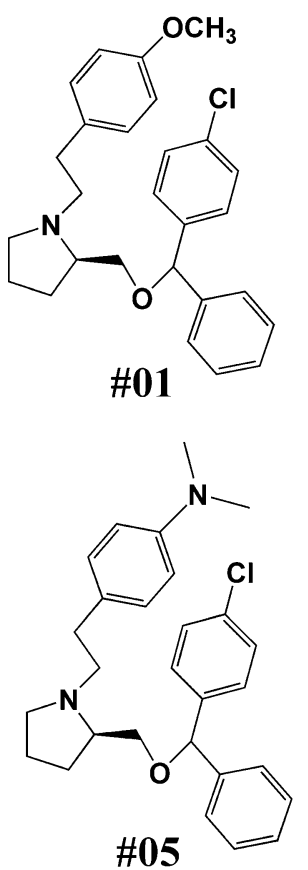<smiles>COc1ccc(CCN2CCC[C@H]2COC(c2ccccc2)c2ccccc2)cc1</smiles>

\#02<smiles>CN(C)c1ccc(CCN2CCC[C@H]2CO)cc1</smiles>

\#06<smiles>COc1ccc(CCN2CCC[C@H]2COCc2ccc(Cl)cc2)cc1</smiles><smiles>OCC[C@H]1CCCN1CCc1ccc(Cl)cc1</smiles><smiles>Clc1ccc(COC(Cn2ccnc2)c2ccc(Cl)cc2Cl)cc1</smiles>

econazole<smiles>Clc1ccc(COC(Cn2ccnc2)c2ccc(Cl)cc2Cl)c(Cl)c1</smiles>

miconazole

Fig. 2 Structures of synthesized compounds that were tested in in vitro assays. Compound \#0I is $\mathrm{TH}-\mathrm{I}$ 177. Econazole and miconazole are controls.

compound \#03 $\left(\mathrm{IC}_{50}=90 \mu \mathrm{M}\right)$, which was over five times less effective at inhibiting TRPV5. Compound \#09, which has a chlorinated benzhydrol group, had the strongest inhibitory effect on TRPV5 $\left(\mathrm{IC}_{50}=109 \mu \mathrm{M}\right)$, with roughly four times less inhibition of TRPV6. Compound \#06, which does not have an ester-linked phenolic side group, did not inhibit either channel and demonstrates that the

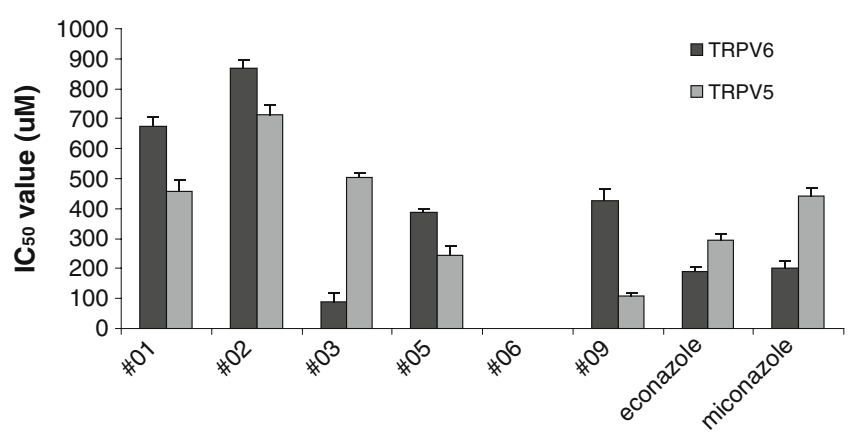

Fig. 3 TRPV-mediated ${ }^{45} \mathrm{Ca}^{2+}$ uptake inhibition. $I C_{50}$ values of tested compounds on TRPV5 and TRPV6 expressed in Xenopus oocytes. presence of an ester-linked side group is critical for activity. Overall, the least effective inhibitors of both channels were compounds \#01 and \#02. Both control compounds, econazole and miconazole, inhibited TRPV6 more than TRPV5. $\mathrm{IC}_{50}$ values and the compound selectivity index (TRPV5/ TRPV6) are displayed in Table I and reveal that compound \#03 is the most potent and selective for TRPV6.

\section{Growth Inhibition in Cancer Cell Lines}

To analyze the effectiveness of our compounds on cancer cell growth, we selected the LNCaP human prostate cancer cell line, since TRPV6 is endogenously expressed and has been reported to play a predominant role in the $\mathrm{Ca}^{2+}$ entry pathway in this cell line (21). To confirm this finding, two distinct siRNAs were used to knock down TRPV6 expression in LNCaP cells. In Fig. 4A, the effectiveness of the siRNA treatments can be seen in their ability to reduce TRPV6 mRNA expression. The siRNA1 reduced expression by $55 \%$ and siRNA 2 by $50 \%$, whereas the control 
Table I IC 50 Inhibition Values and Selectivity Index (TRPV5/TRPV6) of Compounds Tested in TRPV5- or TRPV6-expressing Xenopus Oocytes

\begin{tabular}{llll}
\hline Compound & $I_{50}$ TRPV6 $(\mu M)$ & $I_{50}$ TRPV5 $(\mu M)$ & TRPV5/TRPV6 $^{\text {a }}$ \\
\hline \#01 & 675 & 456 & 0.68 \\
$\# 02$ & 869 & 712 & 0.82 \\
$\# 03$ & 90 & 503 & 5.56 \\
$\# 05$ & 386 & 246 & 0.64 \\
$\# 06$ & No effect & No effect & No effect \\
\#09 & 428 & 109 & 0.25 \\
Econazole & 190 & 296 & 1.56 \\
Miconazole & 201 & 442 & 2.20 \\
\hline
\end{tabular}

${ }^{\text {a }}$ Larger (TRPV5/TRPV6) ratios indicate a more TRPV6-selective compound

siRNA treatment did not affect TRPV6 mRNA. This expression knockdown in turn led to a reduction in LNCaP cell proliferation by $57 \%$ and $52 \%$, respectively (Fig. 4B). Control siRNA treatment did not affect prostate cancer cell growth.

Next, the synthesized compounds were tested for their ability to inhibit the growth of LNCaP prostate cancer cells as well as a breast cancer cell line endogenously expressing TRPV6. Their effectiveness was similar in
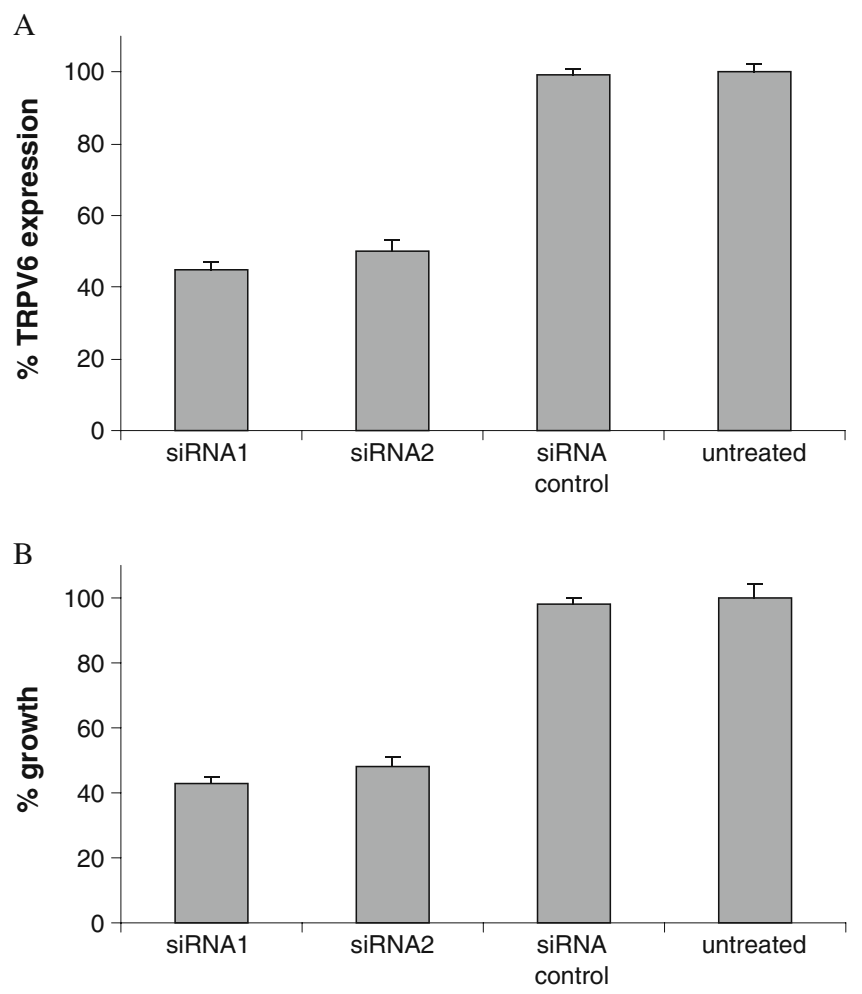

Fig. 4 siRNA knockdown treatments in LNCaP cells. (A) Reduction in TRPV6 expression (\%) after treatment with TRPV6 siRNAs compared to control siRNA. TRPV6 mRNA level standardized to $\beta$-actin. (B) Effect of TRPV6 siRNA treatments on cell viability compared to control siRNA, determined by $\mathrm{XTT}$ assay. pattern to the uptake inhibition data in the oocytes. Compound \#03 was the best growth inhibitor of T47D cells $\left(\mathrm{IC}_{50}=38 \mu \mathrm{M}\right)$ and the second best inhibitor of LNCaP cells $\left(\mathrm{IC}_{50}=0.44 \mu \mathrm{M}\right)$. Likewise, compounds \#01 and \#02 had the weakest effect in both the prostate and breast cancer cells. Compound \#06, which did not show calcium uptake inhibition activity in the oocytes, also showed no effect on reducing cell growth in either cancer cell line (Fig. 5A, B and Table II).

\section{DISCUSSION}

Calcium is a central signaling ion that is crucial for controlling growth, proliferation, and survival of normal and malignant cells. Recent studies have revealed that the calcium entry channel TRPV6 is involved in the growth control of prostate cancer cells via $\mathrm{Ca}^{2+} / \mathrm{NFAT}$-dependent pathways (34). We have also shown that it plays a role in breast cancer, since siRNA knockdown of TRPV6 reduces proliferation in the T47D breast cancer cell line (31).

In this study, we created the first set of chemical compounds directed at TRPV6 inhibition and demonstrated their inhibitory potential in in vitro studies. Compound \#01, TH-1177, was previously shown to inhibit $\mathrm{Ca}^{2+}$ influx into LNCaP human prostate cancer cells (35). However, the molecular target for TH-1177 in LNCaP cells was not
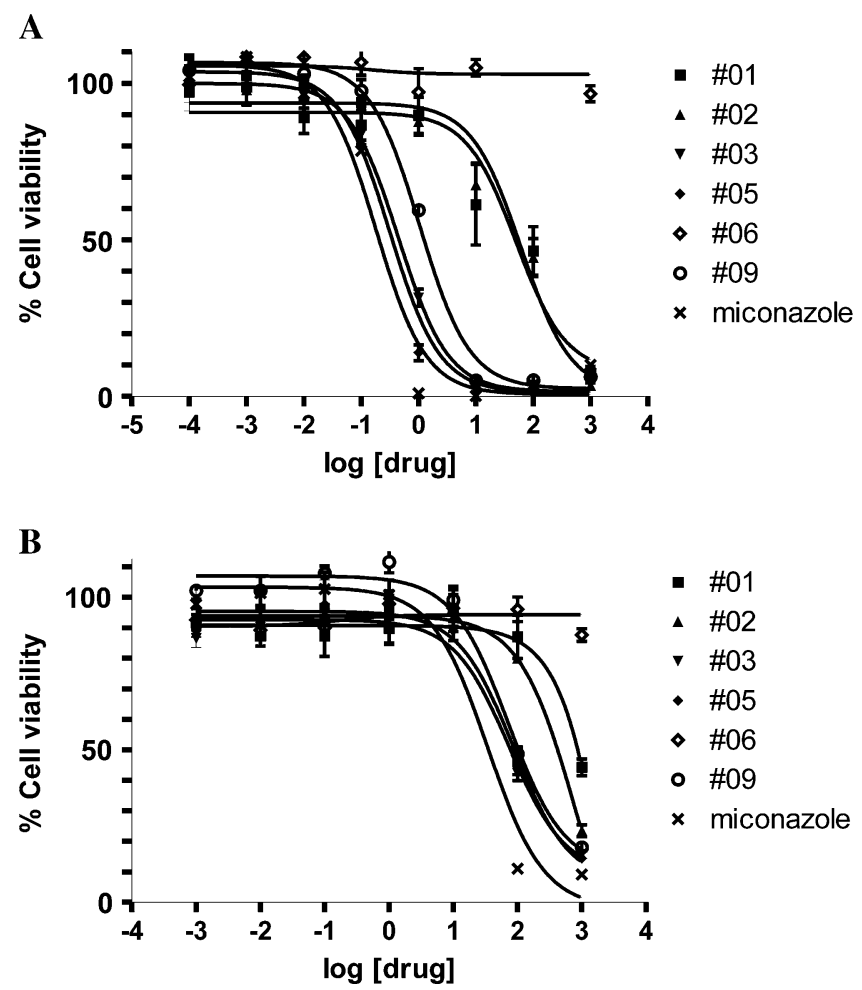

Fig. 5 Viability of LNCaP $(\mathbf{A})$ and T47D $(\mathbf{B})$ cells after treatment with the different synthesized compounds and control (XTT assay), log scale in $\mu \mathrm{M}$. 
Table II IC 50 Inhibition Values of Compounds Tested in LNCaP Prostate Cancer Cells and T47D Breast Cancer Cells

\begin{tabular}{lll}
\hline Compound & $\begin{array}{l}\text { LNCaP } \\
I C_{50}(\mu \mathrm{M})\end{array}$ & $\begin{array}{l}\text { T47D } \\
\mathrm{IC}_{50}(\mu \mathrm{M})\end{array}$ \\
\hline \#0I & $50 \pm 0.4$ & $220.5 \pm 0.9$ \\
$\# 02$ & $61 \pm 0.2$ & $198.2 \pm 0.4$ \\
$\# 03$ & $0.44 \pm 0.07$ & $38.8 \pm 0.2$ \\
$\# 05$ & $0.31 \pm 0.05$ & $44.5 \pm 0.5$ \\
$\# 06$ & No effect & No effect \\
\#09 & $1.0 \pm 0.1$ & $49.1 \pm 0.2$ \\
Miconazole & $0.18 \pm 0.02$ & $40.9 \pm 0.4$ \\
\hline
\end{tabular}

identified. Our experiments using the Xenopus oocyte expression system indicated that TH-1177 inhibited ${ }^{45} \mathrm{Ca}^{2+}$ influx derived from TRPV6 channel activity (Fig. 3). Moreover, it also inhibited TRPV5, the closest homolog of TRPV6 (Fig. 3 and Table I).

To develop more potent and selective inhibitors for TRPV6, we synthesized several compounds based on different chemical modifications of TH-1177 (Fig. 2) and checked their biological activities. Compound \#03 was found to be the most potent and selective for TRPV6 (Fig. 3 and Table I), significantly inhibiting prostate and breast cancer cell proliferation (Fig. 5). Likewise, TRPV6-specific siRNAs were also able to reduce proliferation (Fig. 4), in agreement with previously published studies (34). In LNCaP cells, TRPV6 is the most abundant calcium entry channel and was expressed at levels around 45-fold higher than TRPV5 (37). The calcium channel expression data for T47D cells shows that TRPV6 is among the highest channels expressed (31). The expression of TRPV5 relative to TRPV6 is also dramatically lower. Therefore, we do not expect that TRPV5 plays a major role in calcium uptake in either LNGaP or T47D cells. It has been clearly demonstrated that TRPV6 controls calcium entry and proliferation in LNCaP cells (34). Similarly, in T47D cells, TRPV6 has been shown to play a major role in these processes (31).

The compounds that best inhibited TRPV6-mediated calcium uptake in oocytes were also the best inhibitors of cancer cell growth. A clear correlation was seen between the uptake inhibition and cell viability data. TH-1177 was previously shown to inhibit calcium entry into LNCaP cells, leading to reduced cell proliferation (35). These results strongly suggest that our compounds, especially \#03, inhibit the calcium transport activity of endogenously expressed TRPV6 in prostate and breast cancer cells, and thus lead to lower proliferative ability. The benzyhdrolcontaining compounds \#05 and \#09 were also effective in reducing cancer cell proliferation. While the TRPV6 affinity of these compounds is lower than \#03, it is high enough to produce a significant effect in the proliferation assay. Our compounds might also be inhibiting other calcium entry channels present in the cancer cells. However, we believe the major effect is through TRPV6 inhibition.

Our experiments showed that the presence of an esterbonded phenolic group in the synthesized compounds was critical for the inhibition against TRPV5 or TRPV6, since compound \#06 was unable to inhibit either channel. The control compounds, econazole and miconazole, two other known inhibitors of TRPV5 and TRPV6, also contain this ester-bonded phenolic group at the center of the molecule (Fig. 2). This suggests that the benzhydrol or phenolic group is structurally important, probably reflecting the structure of binding pockets in TRPV5 and TRPV6 channels. Additionally, all the compounds with benzhydrol side groups were more TRPV5-selective, with compound \#09 being the best inhibitor of TRPV5 (Table I). Interestingly, the most TRPV6-selective compound, \#03, contained only an esterlinked chlorinated phenolic side group. Therefore, the nature of the ester-bonded side group seems to play a role in determining the channel selectivity of the compounds.

One can speculate that changing the $\pi$ density of the aromatic groups by introducing different electron releasing/withdrawing groups could be a good strategy for further TRPV5-or TRPV6-targeted drug design, as described for a potassium channel (38). Although we investigated this in a limited way here, we can make a few noteworthy observations. Comparing compounds \#01 and $\# 02$, it is evident that chlorinating the benzhydrol group produced a stronger TRPV-channel inhibitor, since both TRPV5 and TRPV6 were inhibited better by compound \#01. Replacing the methoxyphenolic group (compound \#01) with a chlorinated phenol (compound \#09) further increased the effectiveness of the compound in inhibiting both channels. Compound \#09, containing two chlorinesubstituted phenolic groups, was the best inhibitor of TRPV5. When the chlorinated phenol was replaced with a dimethylaniline, the resulting compound (\#05) became a slightly weaker TRPV5 inhibitor, but was the second best TRPV6 inhibitor. Compound \#05 was the best benzhydrol-containing TRPV6 inhibitor tested. These compounds point the way to developing a larger group of inhibitors to probe deeper into the structure-activity relationships.

The selectivity and potency of compound \#03 suggest that it could be a better compound for in vivo studies than TH-1177. TH-1177 treatment was shown to extend the average life span of mice carrying prostate tumors by up to $38 \%$ without toxicity (34). Therefore, compound \#03 could be expected to perform as well or better. The systemic toxicity of compound $\# 03$ would be expected to be low because of its structural similarity to TH-1177. Studies of the systemic side effects of our compounds, as well as their effectiveness in vivo, are the next step. 


\section{CONCLUSION}

We synthesized TRPV5 and TRPV6 inhibitors and identified one selective inhibitor for TRPV6. Several of our compounds were effective in inhibiting prostate and breast cancer cell proliferation. We propose that this growth inhibition may be caused by a reduction in TRPV6-mediated calcium uptake. Although we did not synthesize sufficient compounds to fully investigate structure-activity relationships, our study provides a starting point for the synthesis of further inhibitory compounds. Future studies will examine the effectiveness of our compounds in in viwo cancer models.

\section{ACKNOWLEDGMENTS}

This study was supported by the Swiss National Science Foundation (Hediger), Novartis Foundation (Hediger), NIH/ NCI (Hediger), Marie Curie Reintegration Grant (Hediger) and Bernese Cancer League (Landowski). We thank Leah Witton for her helpful comments on the manuscript.

\section{REFERENCES}

1. Mettlin G, Jones GW, Murphy GP. Trends in prostate cancer care in the United States, 1974-1990: observations from the patient care evaluation studies of the American College of Surgeons Commission on Cancer. CA Cancer J Clin. 1993;43:83-91.

2. Mundy GR. Mechanisms of bone metastasis. Cancer. 1997;80:1546-56.

3. Orr FW, Sanchez-Sweatman OH, Kostenuik P, Singh G. Tumor-bone interactions in skeletal metastasis. Clin Orthop Relat Res 19-33 (1995).

4. Saitoh H, Hida M, Shimbo T, Nakamura K, Yamagata J, Satoh T. Metastatic patterns of prostatic cancer. Correlation between sites and number of organs involved. Cancer. 1984;54:3078-84.

5. Chanand JM, Giovannucci EL. Dairy products, calcium, and vitamin D and risk of prostate cancer. Epidemiol Rev. 2001;23:87-92.

6. Clinton SK, Giovannucci E. Diet, nutrition, and prostate cancer. Annu Rev Nutr. 1998;18:413-40.

7. Tavani A, Gallus S, Franceschi S, La Vecchia C. Calcium, dairy products, and the risk of prostate cancer. Prostate. 2001;48:118-21.

8. Putney Jr JW. A model for receptor-regulated calcium entry. Cell Calcium. 1986;7:1-12.

9. Putney Jr JW. Type 3 inositol 1, 4, 5-trisphosphate receptor and capacitative calcium entry. Cell Calcium. 1997;21:257-61.

10. Putney Jr JW. Capacitative calcium entry in the nervous system. Cell Calcium. 2003;34:339-44.

11. Hoth M, Penner R. Depletion of intracellular calcium stores activates a calcium current in mast cells. Nature. 1992;355:353-6.

12. Lewis RS, Cahalan MD. Mitogen-induced oscillations of cytosolic $\mathrm{Ca} 2+$ and transmembrane $\mathrm{Ca} 2+$ current in human leukemic $\mathrm{T}$ cells. Cell Regul. 1989;1:99-112.

13. Zweifach A, Lewis RS. Mitogen-regulated Ca2+ current of $\mathrm{T}$ lymphocytes is activated by depletion of intracellular $\mathrm{Ca} 2+$ stores. Proc Natl Acad Sci U S A. 1993;90:6295-9.

14. Shuba YM, Prevarskaya N, Lemonnier L, Van Coppenolle F, Kostyuk PG, Mauroy B, et al. Volume-regulated chloride conductance in the LNCaP human prostate cancer cell line. Am J Physiol Cell Physiol. 2000;279:C1144-54.
15. Zweifach A, Lewis RS. Rapid inactivation of depletion-activated calcium current (ICRAC) due to local calcium feedback. J Gen Physiol. 1995;105:209-26.

16. Abdullaev IF, Bisaillon JM, Potier M, Gonzalez JC, Motiani RK, Trebak M. Stiml and Orail mediate CRAC currents and storeoperated calcium entry important for endothelial cell proliferation. Circ Res. 2008;103:1289-99.

17. Gwack Y, Feske S, Srikanth S, Hogan PG, Rao A. Signalling to transcription: store-operated $\mathrm{Ca} 2+$ entry and NFAT activation in lymphocytes. Cell Calcium. 2007;42:145-56.

18. Ng SW, di Capite J, Singaravelu K, Parekh AB. Sustained activation of the tyrosine kinase Syk by antigen in mast cells requires local $\mathrm{Ca} 2+$ influx through $\mathrm{Ca} 2+$ release-activated $\mathrm{Ca} 2+$ channels. J Biol Chem. 2008;283:31348-55.

19. Stiber J, Hawkins A, Zhang ZS, Wang S, Burch J, Graham V, et al. STIM1 signalling controls store-operated calcium entry required for development and contractile function in skeletal muscle. Nat Cell Biol. 2008;10:688-97.

20. Perret S, Cantereau A, Audin J, Dufy B, Georgescauld D. Interplay between $\mathrm{Ca} 2+$ release and $\mathrm{Ca} 2+$ influx underlies localized hyperpolarization-induced $[\mathrm{Ca} 2+]$ i waves in prostatic cells. Cell Calcium. 1999;25:297-311.

21. Vanden Abeele F, Lemonnier L, Thebault S, Lepage G, Parys JB, Shuba Y, et al. Two types of store-operated Ca2+ channels with different activation modes and molecular origin in LNCaP human prostate cancer epithelial cells. J Biol Chem. 2004;279:3032637.

22. Vanden Abeele F, Roudbaraki M, Shuba Y, Skryma R, Prevarskaya N. Store-operated Ca2+ current in prostate cancer epithelial cells. Role of endogenous $\mathrm{Ca} 2+$ transporter type $1 . \mathrm{J}$ Biol Chem. 2003;278:15381-9.

23. Legrand G, Humez S, Slomianny C, Dewailly E, Vanden Abeele $\mathrm{F}$, Mariot $\mathrm{P}$, et al. $\mathrm{Ca} 2+$ pools and cell growth. Evidence for sarcoendoplasmic Ca2 + -ATPases 2B involvement in human prostate cancer cell growth control. J Biol Chem. 2001;276:4760814.

24. Tombal B, Weeraratna AT, Denmeade SR, Isaacs JT. Thapsigargin induces a calmodulin/calcineurin-dependent apoptotic cascade responsible for the death of prostatic cancer cells. Prostate. 2000;43:303-17.

25. Wertz IE, Dixit VM. Characterization of calcium releaseactivated apoptosis of LNCaP prostate cancer cells. J Biol Chem. 2000;275:11470-7.

26. Skryma R, Mariot P, Bourhis XL, Coppenolle FV, Shuba Y, Vanden Abeele F, et al. Store depletion and store-operated Ca2+ current in human prostate cancer LNCaP cells: involvement in apoptosis. J Physiol. 2000;527(Pt 1):71-83.

27. Vanden Abeele F, Skryma R, Shuba Y, Van Coppenolle F, Slomianny C, Roudbaraki M, et al. Bcl-2-dependent modulation of $\mathrm{Ca}(2+)$ homeostasis and store-operated channels in prostate cancer cells. Cancer Cell. 2002;1:169-79.

28. Wissenbach U, Niemeyer BA, Fixemer T, Schneidewind A, Trost C, Cavalie A, et al. Expression of CaT-like, a novel calciumselective channel, correlates with the malignancy of prostate cancer. J Biol Chem. 2001;276:19461-8.

29. Fixemer T, Wissenbach U, Flockerzi V, Bonkhoff H. Expression of the Ca2+-selective cation channel TRPV6 in human prostate cancer: a novel prognostic marker for tumor progression. Oncogene. 2003;22:7858-61.

30. Zhuang L, Peng JB, Tou L, Takanaga H, Adam RM, Hediger MA, et al. Calcium-selective ion channel, CaT1, is apically localized in gastrointestinal tract epithelia and is aberrantly expressed in human malignancies. Lab Invest. 2002;82:175564.

31. Bolanz KA, Hediger MA, Landowski CP. The role of TRPV6 in breast carcinogenesis. Mol Cancer Ther. 2008;7:271-9. 
32. Bodding M, Flockerzi V. Ca2+ dependence of the Ca2+-selective TRPV6 channel. J Biol Chem. 2004;279:36546-52.

33. Schindl R, Kahr H, Graz I, Groschner K, Romanin C. Store depletion-activated CaT1 currents in rat basophilic leukemia mast cells are inhibited by 2-aminoethoxydiphenyl borate. Evidence for a regulatory component that controls activation of both CaT1 and CRAC $(\mathrm{Ca}(2+)$ release-activated $\mathrm{Ca}(2+)$ channel) channels. J Biol Chem. 2002;277:26950-8.

34. Lehen'kyi V, Flourakis M, Skryma R, Prevarskaya N. TRPV6 channel controls prostate cancer cell proliferation via $\mathrm{Ca}(2+) /$ NFAT-dependent pathways. Oncogene. 2007;26:7380-5.

35. Haverstick DM, Heady TN, Macdonald TL, Gray LS. Inhibition of human prostate cancer proliferation in vitro and in a mouse model by a compound synthesized to block Ca2+ entry. Cancer Res. 2000;60:1002-8.

36. Peng JB, Chen XZ, Berger UV, Vassilev PM, Tsukaguchi H, Brown EM, et al. Molecular cloning and characterization of a channel-like transporter mediating intestinal calcium absorption. J Biol Chem. 1999;274:22739-46.

37. Peng JB, Zhuang L, Berger UV, Adam RM, Williams BJ, Brown $\mathrm{EM}$, et al. CaT1 expression correlates with tumor grade in prostate cancer. Biochem Biophys Res Commun. 2001;282:729-34.

38. Imai YN, Ryu S, Oiki S. Docking model of drug binding to the human ether-a-go-go potassium channel guided by tandem dimer mutant patch-clamp data: a synergic approach. J Med Chem. 2009;52:1630-8. 